\title{
Impact of Electronic Agreements from the Viewpoint of the Indonesian Civil Code
}

\author{
Indrati Rini ${ }^{1}$, Soesi Idayanti ${ }^{2}$ \\ ${ }^{1}$ Universitas Narotama Surabaya, Indonesia \\ 2Universitas Pancasakti Tegal, Indonesia \\ Email: indratirini1956@gmail.com, soesi idayanti@upstegal.ac.id
}

\begin{abstract}
There are often legal problems, both concerning issues of authenticity, authenticity and proof because there is no law that specifically regulates personal data of agreement users via electronic means. The problem raised is how the problem of the authenticity, authenticity and integrity of the agreement electronically and how the validity of an agreement made electronically. The research method that the author uses is normative qualitative by using secondary data and reinforced by primary data or field data. The results of the study show that the authenticity, authenticity and integrity of the agreement electronically can be carried out using digital forensic tools. The use of information through electronic media concerning a person's personal data must be carried out with the consent of the person concerned. Agreements made electronically/digitally have the same evidentiary power as agreements made through manuals. Judges can use the evidentiary system with the development towards open evidence. Evidence obtained from anywhere as long as the truth can be accepted as long as it does not conflict with public order, considering that in conducting transactions in the current digital era, we will often use online media.
\end{abstract}

Keywords: Electronic Agreement, Criminal Code, Civil Law.

\section{A. INTRODUCTION}

The effects of advances in the field of electronic technology, the behavior of the world community in carrying out activities both in the field of agreements and other activities are almost all carried out electronically. It is as if humans can easily carry out legal relations with other humans without time and territory limits. Seeing things like that, the rule of law is required to intervene, so that in conducting transactions electronically, the word order and certainty and justice can be achieved for the parties in conducting transactions via electronic whatever form the transaction takes.

If the agreement has fulfilled the legal requirements of the agreement, then the agreement is binding on both parties and must be carried out in good faith. In entering into an agreement, the elements as stated in Article 1320 of the Civil Code must be fulfilled. In the trial to provide certainty to the judge, both parties must be able to prove something that has really happened so that the judge feels sure that what is being proven is something that is true. This is called proof.

The diversity of laws and jurisdictions that bind both parties raises doubts about the law and legal jurisdiction that binds both parties in conducting electronic agreements. Until now, there are still those who argue that agreements made electronically are not valid because they are considered unreal and are still in cyberspace / in fantasy. Actually, the existence of an agreement via electronic means 
that there are two parties who actually exist, not in cyberspace / in fantasy (Sa'adah \& Indriawati, 2020).

Electronic transactions can be directly carried out by sellers and buyers or can also be carried out using intermediary applications available in cyberspace, such as Tokopedia, Shopee and Bukalapak. In electronic transactions, of course, it cannot be separated from the existence of data that is electronically provided, this is used to facilitate the transaction itself. Of course the data that has been given to the provider of the electronic transaction intermediary application is data that must be protected by the provider, because if the data is known by other parties, the transaction will not be in accordance with what is desired by the transacting parties. This case occurred in the electronic transaction intermediary application provider Bukalapak, where there were 91 million application user data leaked (CNBC Indonesia, 2020). In this dispute, of course, it cannot be separated from the use of electronic evidence from both the plaintiff and the defendant. From the example of the case, in this case the author will dissect Article 1320 of the Civil Code regarding the terms of the validity of the agreement, Law Number 19 of 2016 concerning Information and Electronic Transactions then Article 163 HIR in conjunction with Article 1866 of the Civil Code with regard to the types of evidence.

With reference to the background of the description above, it is necessary to formulate a problem to facilitate the process of solving the problems raised in this research, the first is how to issue authenticity, authenticity and integrity of electronic agreements; second, how the validity of an agreement made electronically.

\section{B. METHOD}

This research is a sociological legal research, which sees law as an empirical social phenomenon. This research is to uncover the problems behind the implementation and enforcement of the law. This research is descriptive in nature, to collect information about the status of a variable or theme, existing symptoms or circumstances, namely the state of symptoms according to what they were at the time the research was conducted. This study describes the arrangement and implementation of the validity of the agreement verification which is carried out electronically in terms of Article 1866 and the ITE Law. The data used in this study is secondary data and is reinforced by primary data or field data. The primary data are the results of interviews from officials from the Ministry of Communication and Information and the Tangerang District Court.

\section{RESULT AND DISCUSSION}

\section{Problems with the Authentic, Authenticity and Integrity of Electronic} Agreements.

One of the "problems with the authenticity, authenticity and integrity of the electronic agreement" is to prove that the information or document is authentic, for example: how to prove that the parties have given their consent electronically with an electronic signature? The regulation of electronic evidence that exists to date is 
only at the level of material law, namely in Law Number 19 of 2016 concerning Information and Electronic Transactions (Dotulong, 2014).

Civil procedural law in Indonesia still has problems in terms of electronic proof law related to electronic signatures on documents (Saruji \& Martana, 2015). According to Arif Budi Cahyono, the Tangerang District Court judge when interviewed regarding the agreement via electronic means that: "With the existence of digital forensics. Digital forensics is a method used to identify, collect, analyze and test digital evidence for a legal case.

Furthermore, Arif Budi Cahyono, a judge at the Tangerang District Court when interviewed, added that, "There is no legal regulation related to e-commerce. Currently using the standard "terms of agreement" agreement on the e-Commerce page. Once we click "I accept", it means that we have automatically submitted ourselves and bound ourselves to the agreements and regulations of the eCommerce that we use.

Furthermore, Arif Budi Cahyono explained that: "According to the Supreme Court, electronic evidence is included as evidence if it is linked to Article 184 of the Criminal Procedure Code. What needs to be considered is if the electronic evidence is denied by the opponent. So that's why we use digital forensics to find out the authenticity of the evidence. For example, photos can be changed and edited. This is where the role of digital forensics is to test its authenticity to ensure that the photo is taken from any source and is original without editing. An example is the Antasari case where there is evidence that he exchanged messages with the perpetrators, even though according to an ITB expert it was not sent from his cellphone. Provider can be defined as a company or business entity that provides services to users. Providers can sometimes also be referred to as companies that usually serve the creation of websites, regulate their placement in the cyber world (including maintenance and provision of Internet access) as well as help in terms of promotion so that the website is visited by Internet users.

According to Ruby Zukri Alamsyah, a forensic expert, revealing that "Citizens can report the provider to the police if it is proven that there are non-law enforcement civilians who intentionally leak personal data without the permission of the owner", the provider will be reprimanded or sanctioned from the BRTI (Indonesian Telecommunications Regulatory Agency) (Jelita , 2020).

Josua Sitompul (2020) as Coordinator of Law and Cooperation of KOMINFO in his answer to our Research and Research questions stated that "Electronics is easy to change, add, or reduce. Therefore, the acceptance of electronic information as a valid evidence (admissibility) is determined by the certainty that the authenticity and availability of the information is maintained. The meaning of authentic is not that the electronic information is made by an authorized official. There are at least two things that must be considered in determining the authenticity of an electronic information or document. First, electronic information is called authentic in the event that the source of the electronic information comes from a person or party 
who has the right or authority to issue the said electronic information or document. Second, the content or content is the content intended by the source.

As stated in Article 26 paragraph (1) of the Law on Information and Electronic Transactions which states that: "Unless stipulated otherwise by laws and regulations, the use of any information through electronic media concerning a person's personal data must be carried out with the consent of the person concerned. Therefore, if personal data is violated, such as the case of leaking personal data, the party who feels that their rights have been violated can file a lawsuit. Article 5 paragraph (1) of the ITE Law expressly stipulates that Electronic Information or Documents and/or their printouts are legal evidence. What is meant by Electronic Information is as referred to in Article 1 point 1 of the ITE Law. Meanwhile, what is meant by Electronic Documents is as regulated in Article 1 number 4 of the ITE Law. Electronic information and documents can be distinguished but cannot be separated. In simple terms, the difference between Electronic Information and Electronic Documents is that Electronic Information is data while Electronic Documents are the format of data. For example, in files in the form of doc, pdf, mp3, and jpg, Electronic Information is the words or writings, letters, numbers contained in the file. While the Electronic Documents are doc, pdf, mp3, jpg.

Then, Article 5 paragraph (2) of the ITE Law stipulates that Electronic Information and/or Electronic Documents and/or their printed results are an extension of legal evidence in accordance with the procedural law applicable in Indonesia. This arrangement is an innovation in the ITE Law to bridge the old rules and principles regarding evidence (which must be in physical form) and technological developments.

The expansion of legal evidence in the Civil Procedure Code means: Expanding the scope or scope of evidence as regulated in Article 186 of the Civil Code, namely expanding written or letter evidence. In this case, the extension is a printed result of information or electronic documents. It is another means of evidence, namely increasing the amount of evidence regulated in Article 186 of the Civil Code, namely information or electronic documents and is referred to as electronic evidence.

\section{The Validity of the Agreement through Electronic Judging from Article 1866 of the Civil Code.}

With the agreement, it creates legal consequences that each party is obliged to carry out the rights and obligations because they have agreed to the contents of the agreement, where the rights and obligations in the agreement are called achievements (S'adah, 2018). The legal consequences of the agreement are due to legal actions, where the legal action occurs because there is a statement of will from both parties that causes the consequences regulated by law, namely to carry out rights and obligations (Arthaluhur, 2018).

According to Subekti (2002), an agreement is an event where one person promises to another person or where two people promise each other to do 
something. Based on Article 1313 of the Civil Code states that "Agreement is an act where one or more people bind themselves to one or more other people". In Article 1320 of the Civil Code it is stated, for the validity of an agreement, four conditions are needed, namely: Agree on those who bind themselves, meaning that the parties who enter into the agreement must agree or agree on the agreement to be held, without any coercion, oversight and fraud. According to Bambang (2013), there are 4 theories to say that an agreement has been reached, namely: Pronunciation Theory; Delivery Theory; Theory of Knowledge and Theory of Acceptance The ability to make an engagement, meaning that the parties who will make an agreement must be legally capable, if there are parties who are not legally capable, the agreement can be canceled. Based on Article 1330 states that "Incompetent to make an agreement are: First, people who are not yet mature, meaning that people who are not yet adults are prohibited from entering into agreements, the law stipulates that those who are not yet adults are those who have not reached the age of 21 years; Second; those who are placed under guardianship, meaning that people who are still under guardianship cannot make an agreement, if they make an agreement they will be represented by the guardian; and third, women, in matters stipulated by law, and in general everyone to whom the law has prohibited making certain agreements, meaning that women are among those who are not legally capable, but After the marriage law is born, this rule does not apply. The marriage law stipulates that women are legal subjects who are capable as long as they are adults and there are no other problems. A certain thing means that in the agreement the object of achievement to be given must be clear and definite and can be used by both parties, not still in the imagination or still planned. A lawful cause, meaning that the agreement is in accordance with the existing legal rules, does not violate the law, morality or public order.

Electronic agreements are also recognized by the United Convention on the Use of Electronic Communication in International Contracts as stated in Article 8 paragraph (1) which is a binding and legal agreement according to law (Prasojo, 2020).

Josua Sitompul (2020) stated that "The validity of printed electronic information depends on the validity of the information and electronic documents. If the information or electronic document is valid then the printed result is also valid. In order for information or electronic documents to be valid, there must be fulfillment of the following requirements.

1. Article 5 paragraph (4) of the ITE Law which stipulates that a letter which according to the law must be made in written form or letters and documents which according to the law must be made in the form of a notarial deed or a deed made by the official making the deed. In this case, the electronic form of the letter or document cannot be used as legal evidence. The formal requirements regulated in the Civil Code are an underhand deed or other letter recognized by the interested party. 
2. Article 6 of the ITE Law, Electronic Information and/or Electronic Documents are considered valid as long as the information contained therein can be accessed, displayed, guaranteed for its integrity, and can be accounted for so as to explain a situation.

3. Article 7 of the ITE Law, any person who declares rights, strengthens existing rights, or rejects the rights of others based on the existence of Electronic Information and/or Electronic Documents must ensure that the Electronic Information and/or Electronic Documents in his possession originate from the Electronic System that meet the requirements based on the Laws and Regulations.

Furthermore, Josua Sitompul (2020) said that "Regarding electronic signatures, the ITE Law and PP 71/2019 regulate the existence of uncertified electronic signatures (for example in scanned form), and certified signatures. Certified signatures using trusted third parties. Both types of signatures have legal force and legal consequences as long as the provisions of Article 11 of the ITE Law are met".

The Telecommunications Law Number 36 of 1999 concerning Telecommunications in Article 2 states that telecommunications is carried out based on the principles of benefit, fairness and equity, legal certainty, security, partnership, ethics, and self-confidence. National unity and integrity, improve the welfare and prosperity of the people in a fair and equitable manner, support economic life and government activities, and improve relations between nations.

According to Sudikno Mertokusumo (2006) that "Proof contains logical, conventional and juridical meanings. In a logical sense, is to provide absolute certainty. In the conventional sense it means certainty but not absolute certainty. In a juridical sense, it is proof that provides the truth that applies only to the litigants".

M. Yahya Harahap (2005) said that "What is meant by the general principle of proof is the basis for the application of evidence. All parties, including judges, must adhere to the standards outlined by these principles. Indeed, besides that, there are still special principles that apply to each type of evidence, so they must be used as a benchmark in the application of the evidence system. However, what is discussed in general principles is a provision that applies to the system of evidence in general.

According to Arif Budiman (2020), the Tangerang District Court judge when interviewed explained Article 5 paragraph (1) of the Electronic Information and Transaction Law, stating that: "Electronic Information and/or Electronic Documents and/or their printed results are legal evidence". In addition, electronic evidence opens space for judges to accept other evidence and be recognized as evidence.

Regarding instruments, the civil procedural law in the Republic of Indonesia recognizes evidence as regulated in Article 164 HIR and Article 1866 of the Civil Code, namely: First, writing; Second, Witness; Third, conjectures, Fourth; Confession and fifth, Oath.

According to M. Yahya Harahap (2005) that "the evidentiary system adopted to date is as follows: Closed and Limited System the parties are not free to submit 
the type or form of evidence in the case settlement process. The development towards open evidence in the law of evidence is no longer determined by certain types or evidence, but from any evidence, the truth must be accepted as long as it does not conflict with public order.

\section{CONCLUSION}

Electronic information is easy to change, add, or subtract. Therefore, the acceptance of electronic information as a valid evidence (admissibility) is determined by the certainty that the authenticity and availability of the information is maintained. The meaning of authentic is not that the electronic information is made by an authorized official. There are at least two things that must be considered in determining the authenticity of an electronic information or document. First, electronic information is called authentic in the event that the source of the electronic information comes from a person or party who has the right or authority to issue the said electronic information or document. Second, the content or content is the content intended by the source. The required electronic information must be accessible to the parties including the courts for evidentiary purposes. In civil law there is a general principle that whoever postulates, he must prove. The validity of the agreement via electronic is recognized by the ITE law which is information or documents that are carried out electronically. If a dispute occurs, it can be brought to legal channels, where if it comes to a trial the judge can use a proof system with developments towards open evidence.

\section{REFERENCES}

1. Bambang, J. R. (2013). Hukum Ketenagakerjaan. Bandung: Pustaka Setia.

2. CNBC Indonesia. (2020). Buka-bukaan Bos Tokopedia Soal Bocornya 91 Juta Data Pengguna. Retriaved from https://www.cnbcindonesia.com/tech/2020051213350637-157889/buka-bukaan-bos-tokopedia-soal-bocornya-91-juta-data-pengguna

3. Dotulong, T. (2014). Keberadaan Alat Bukti Elektronik Dalam Penyelesaian Sengketa Perdata. Lex Privatum, 2(3).

4. Harahap, M. Y. (2005). Hukum Acara Perdata. Jakarta: Sinar Grafika.

5. idcloudhost.com. Kamus Hosting Provider. Retrieved from https://idcloudhost.com/kamus-hosting/provider/

6. Jelita, I. N. (2020). Data Seluler Bocor, Warga Bisa Tuntut Provider ke Polisi. Retrieved from https://mediaindonesia.com/read/detail/325719-data-selulerbocor-warga-bisa-tuntut-provider-ke-polisi

7. Law Number 36 of 1999 concerning Telecommunications.

8. Law Number 19 of 2016 concerning Information and Electronic Transactions.

9. Law Number 16 of 2019 concerning Amendments to Law 1 of 1974 concerning Marriage.

10. Mertokusumo, S. (2006). Hukum Acara Perdata Indonesia. Yogyakarta: Liberty. 
11. Pertiwi, W. K. (2020). Sidang Perdana Kasus Kebocoran Data Tokopedia Digelar Hari Ini. Retrieved from https://tekno.kompas.com/read/2020/06/10/09144017/sidangperdana-kasus-kebocoran-data-tokopedia-digelar-hari-ini?page=all

12. Prasojo, D. (2019). Hal-hal Penting Dalam Perjanjian Elektronik (Clik Wrap Agreement). Retrieved from https://www.daya.id/usaha/artikel-daya/hukumperizinan/hal-hal-penting-dalam-perjanjian-elektronik-clik-wrap-agreement-

13. Sa'adah, N. (2020). Akibat Hukum Pembuktian Perjanjian Tidak Tertulis (Analisis Putusan Nomor: 373/pdt.g/2016/pnMdn). Pamulang Law Review, 1(2), 137-150.

14. Saruji, P. V., \& Martana, N. A. Kekuatan Hukum Pembuktian Tandatangan Pada Dokumen Elektronik Sebagai Alat Bukti Dalam Hukum Acara Perdata. Kertha Semaya: Journal Ilmu Hukum, 4(2).

15. Sitorus, D. A. (2015). Perjanjian Jual Beli Melalui Internet (E-Commerce) Ditinjau Dari Aspek Hukum Perdata. Retrieved from http://ejournal.uajy.ac.id/7998/1/JURNAL.pdf

16. Subekti. (2002). Hukum Perjanjian. Jakarta: Intermasa. 